\title{
KARAKTERISTIK PERTUMBUHAN EKONOMI DAN SEKTOR BASIS PROVINSI DI INDONESIA PADA MASA PANDEMI COVID-19
}

\author{
(Characteristic of Economic Growth and Base Sector of Indonesian Provinces in The Time \\ of Covid-19 Pandemic)
}

\author{
Mohammad Ammar Alwandi ${ }^{1}$, Siti Muchlisoh² \\ Politeknik Statistika STIS ${ }^{1}$ \\ Politeknik Statistika STIS ${ }^{2}$ \\ Jalan Otto Iskandardinata No.64C Jakarta Timur \\ E-mail: 16.9277@stis.ac.id
}

\begin{abstract}
ABSTRAK
Pandemi Covid-19 membuat perekonomian Indonesia terkontraksi 5,32 persen. Hampir semua lapangan usaha mengalami tekanan di triwulan II-2020. Hal ini disebabkan karena terjadi penularan masif Covid-19 di pabrik-pabrik dan perkantoran. Ditambah lagi, penerapan pembatasan sosial berskala besar (PSBB) membuat konsumsi rumah tangga menurun. Dampak pandemi di setiap provinsi tentu berbeda antara satu dengan lainnya sehingga kebijakan yang diambil tidak bisa disamaratakan. Oleh karena itu, penelitian ini bertujuan untuk menganalisis karakteristik pertumbuhan ekonomi dan sektor basis pada provinsi di Indonesia pada masa pandemi Covid-19. Penelitian ini menggunakan metode Location Quotient untuk mengidentifikasi sektor basis di setiap provinsi dan metode $K$-Means Clustering untuk memetakan karakteristik masing-masing provinsi. Hasil dari penelitian ini adalah provinsi dengan sektor basis pertanian dan memiliki risiko penularan Covid-19 yang rendah relatif tidak terkontraksi terlalu dalam. Dengan demikian, pemerintah harus tetap mengutamakan pencegahan penularan Covid-19 sekaligus memulihkan perekonomian yang dimulai dari sektor pertanian.
\end{abstract}

Kata kunci: kontraksi ekonomi, sektor basis, covid-19, k-means, Indonesia

\section{ABSTRACT}

The Covid-19 pandemic caused Indonesia's economy to contract by 5.32 percent. Almost all business fields came under pressure in the second quarter of 2020. This is due to the massive transmission of Covid19 in factories and offices. In addition, the implementation of large-scale social restriction (PSBBs) has decreased household consumption. The impact of a pandemic in each province is certainly different from one another, so that the policies cannot be generalized. Therefore, this study aims to analyze the characteristics of economic growth and base sector in provinces in Indonesia during the Covid-19 pandemic. This study uses the Location Quotient method to identify base sector in each province and K-Means Clustering method to map the characteristics of each province. The result of this study are provinces with an agricultural base sector and have low risk of Covid-19 transmissions which is relatively have low economic contraction. Thus, the government must continue to prioritize preventing the spread of Covid-19 while at the same time restoring the economy from agricultural sector.

Keywords: economic contraction, basis sector, covid-19, k-means, Indonesia

\section{PENDAHULUAN}

Sejak diumumkannya kasus pertama Covid-19 oleh Presiden Joko Widodo pada Maret 2020, Indonesia masih belum bisa menjinakkannya sampai penelitian ini ditulis pada bulan September 2020. Dampak pertama yang ditimbulkan pagebluk ini kolapsnya sistem kesehatan Indonesia yang memang sudah rapuh (Olivia, Gibson, \& Nasrudin, 2020). Menurut Todaro dan Smith (2011), kesehatan merupakan modal dasar pembangunan ekonomi. Perekonomian akan ikut terinfeksi apabila penduduk di suatu wilayah kesehatannya buruk. Pada akhirnya, pandemi ini turut memukul perekonomian Indonesia yang pada triwulan-II 2020 terkontraksi 5,32 persen secara year on year (BPS, 2020). 
Dilihat dari kontribusi setiap pulau terhadap PDB nasional, Pulau Jawa menyumbang 58,55 persen PDB Nasional pada triwulan-II 2020. Hal ini menunjukkan apabila perekonomian Pulau Jawa terkontraksi, Indonesia akan ikut terkontraksi. Per 7 September 2020, Pulau Jawa masih menjadi episentrum Covid-19 yang menyumbang 66,3 persen kasus baru secara nasional (Katadata, 2020). Tak mengejutkan jika perekonomian di pulau terpadat se-Indonesia itu terkontraksi sebesar 6,69 persen pada triwulan-II 2020 year on year karena diterapkannya pembatasan sosial berskala besar (PSBB) untuk memutus mata rantai penularan Covid-19.

Hampir seluruh lapangan usaha di Indonesia terkontraksi. Lapangan usaha yang masih mampu tumbuh positif adalah pertanian, informasi komunikasi, jasa kesehatan, dan pengadaan air. Tentu, provinsi yang perekonomiannya bertumpu pada lapangan usaha yang masih tumbuh positif dapat menahan kedalaman kontraksi perekonomian. Sebagai negara kepulauan yang terpisah oleh laut, tentunya karakteristik perekonomian pada masing-masing provinsi berbeda. Oleh karena itu, masing-masing provinsi harus membuat strategi pemulihan ekonomi berdasarkan karakteristik perekonomian di daerahnya. Penelitian ini bertujuan untuk melakukan analisis karakteristik lapangan usaha basis dan kondisi pertumbuhan ekonomi pada masing-masing provinsi di Indonesia pada masa pandemi Covid-19.

\section{METODE}

\section{Peran Kesehatan terhadap Produktivitas Pekerja}

Todaro dan Smith (2011) menyebutkan bahwa kesehatan sangat penting artinya bagi kesejahteraan. Kesehatan merupakan prasyarat bagi peningkatan produktivitas. Dengan baiknya kualitas kesehatan, seseorang relatif akan memiliki usia yang lebih panjang. Hal ini membuat pekerja dapat menghasilkan pendapatan dengan jangka waktu yang lebih lama. Selain itu, investasi dibidang kesehatan adalah sarana untuk mengurangi kemiskinan. Dengan demikian, pemerintah harus memandang investasi modal manusia, dalam hal ini kesehatan, sama pentingnya dengan investasi di modal fisik.

Bank Dunia dalam Wisana (2001) menyatakan bahwa apabila investasi pada sumber daya manusia dilakukan dengan tepat akan menghasilkan dasar berpijak yang kuat bagi proses pembangunan manusia yang pesat dan berkelanjutan. Kesehatan, seperti halnya pendidikan, merupakan bidang yang terkait langsung dengan sumber daya manusia. Namun, keduanya sering tidak mendapat perhatian yang serius dan komprehensif, apalagi bila alasan keterbatasan anggaran dikemukakan. Sebagai sebuah investasi yang "ditanamkan" kepada manusia, kesehatan digunakan untuk meraih manfaat berupa produktivitas dan pendapatan yang lebih tinggi bagi pekerja.

Ukuran yang dipakai untuk melihat status kesehatan berupa angka kematian dan angka kesakitan. Akibat dari timbulnya kesakitan (sickness) terhadap produktivitas pekerja yaitu kematian (kehilangan pekerja), ketidakmampuan (kehilangan jam kerja), kecacatan (kehilangan kapasitas kerja). Dengan masih mengganasnya penularan virus corona, tentu status kesehatan akan menurun yang praktis akan berdampak pada turunnya produktivitas pekerja di hampir seluruh lapangan usaha.

\section{Indeks Kerentanan Covid-19}

Untuk menggambarkan kerentanan masing-masing provinsi dalam menghadapi pandemi Covid-19, Katadata (2020) mengeluarkan Indeks Kerentanan Covid-19 pada 6 April 2020. Indeks yang memiliki rentang 0-100 tersebut dihitung berdasarkan tiga sub indikator yakni sebagai berikut:

1. Risiko Mobilitas Penduduk yang dihitung dari:

- Jumlah Penumpang Kapal Laut di Pelabuhan Utama per Penduduk

- Jumlah Penumpang Pesawat per Penduduk

- Persentase Pekerja dengan Jarak Lebih Dari 10 km dari Tempat Tinggal

- Persentase Pekerja Menggunakan Transportasi Umum dan Transportasi Bersama

- Persentase Pekerja yang Bekerja di luar Kabupaten Tempat Tinggal

2. Risiko Kondisi Kesehatan Penduduk yang dihitung dari: 
- Konsumsi Protein per Kapita per Hari (gram)

- Morbiditas Rate

- Persentase Penduduk Merokok Usia > 15 Tahun

- Persentase Penduduk Sakit yang Tidak Mampu Rawat Inap

- Persentase Penduduk Umur lebih dari 64 tahun

- Persentase Penduduk yang Tidak Memiliki Akses Jaminan Kesehatan

3. Risiko Karakteristik Daerah yang dihitung dari:

- Indeks Kualitas Udara

- Jumlah Penduduk

- Kepadatan Penduduk

- Persentase Balita yang Mendapat Imunisasi Lengkap

- Persentase Rumah Tangga yang Memiliki Akses Hunian yang Layak dan Terjangkau

Dengan demikian, semakin tinggi nilai Indeks Kerentanan Covid-19 maka semakin rentan provinsi tersebut menghadapi Covid-19. Menurut Mulya Amri, Direktur Katadata Insight Center, dalam Press Briefing "Siapkah Daerah Menghadapi Pandemi: Peluncuran Indeks Kerentanan Provinsi terhadap Covid-19", provinsi yang sangat rentan sekaligus tidak memiliki fasilitas kesehatan yang memadai harus mendapatkan perhatian serius.

\section{Penularan Covid-19 dan Dampaknya di Indonesia}

Menurut Lindsey dan Mann dalam Olivia, Nasrudin, dan Gibson (2020), pemerintah Indonesia menuai kritik dari dalam maupun luar negeri karena respons yang tidak cukup cepat dalam menghadapi kedaruratan pandemi. Sejak bulan Februari, ketika Malaysia dan Singapura menyatakan penularan Covid-19 yang masif, Indonesia mengklaim tidak memiliki kasus sama sekali. Pada 9 Maret 2020, Presiden Jokowi baru melaporkan dua kasus konfirmasi Covid-19. Pada saat itu, negara tetangga Indonesia melakukan tes masal dan pembatasan sosial untuk memutus mata rantai penularan di masyarakat. Sementara Indonesia belum melakukan pembatasan sosial dengan alasan akan merusak perekonomian. Oleh sebab itu, pada saat penelitian ini ditulis, 59 negara telah melarang kunjungan WNI memasuki negara mereka karena tingkat penularan yang semakin tak terkendali (Tempo, 2020).

Komplikasi berikutnya adalah masalah kelembagaan membuat Indonesia kesulitan untuk menghentikan penularan Covid-19. UU No. 6 Tahun 2018 tentang Karantina Kesehatan tidak dipakai dalam menghadapi pandemi. Hal ini membuat koordinasi pemerintah pusat dan daerah menjadi sulit. Sebagai contoh, pemerintah pusat menganulir keputusan DKI Jakarta pada Maret 2020 untuk melakukan pembatasan mobilitas masyarakat. Akan tetapi, pada akhirnya pemerintah pusat mengizinkan Pembatasan Sosial Berskala Besar (PSBB) melalui Peraturan Menteri Kesehatan No. 9 Tahun 2020. Pada saat penelitian ini ditulis, rencana DKI Jakarta untuk kembali menerapkan PSBB Total pada 14 September 2020, menuai protes dari para Menteri Kabinet Indonesia Maju karena alasan PSBB dapat memperburuk ekonomi nasional (Tirto, 2020).

\section{Analisis Location Quotient (LQ)}

Analisis LQ merupakan suatu alat analisis untuk menunjukkan basis ekonomi wilayah terutama dari kriteria kontribusi terhadap PDB Nasional (Wibisono, 2003). Di samping itu, LQ adalah suatu indeks untuk mengukur tingkat spesialisasi (relatif) suatu sektor atau sub-sektor ekonomi suatu wilayah tertentu (Bendavid, 1991). LQ dirumuskan dengan formula sebagai berikut:

$$
L Q=\frac{l_{i} / l_{t}}{L_{i} / L_{t}}
$$

dimana:

$l_{i} \quad=$ PDRB lapangan usaha ADHK ke $i$ provinsi,

$l_{t}=$ total PDRB ADHK provinsi,

$L_{i}=$ PDB ADHK lapangan usaha ke $i$,

$L_{t} \quad=$ PDB ADHK Nasional. 
Jika hasil perhitungan bernilai LQ $>1$, maka industri tersebut tergolong sektor basis di daerah tersebut. Hal ini menunjukkan bahwa pangsa output industri unggulan di tingkat provinsi tersebut lebih besar dibandingkan dengan tingkat nasional. Sebaliknya, jika nilai LQ $<1$, maka industri tersebut bukan sektor basis di daerah tersebut.

\section{Analisis $K$-Means Clustering}

Menurut University of Cincinnati (2018), Clustering adalah seperangkat teknik yang luas untuk menemukan sub-kelompok dari observasi dalam satu dataset. Tujuan Clustering adalah mengelompokkan observasi berdasarkan kesamaan karakteristik yang dimilikinya dengan meminimalkan variasi di dalam klaster (minimzing total within-cluster sum of squares) K-Means Clustering adalah metode clustering yang paling sederhana dan sering digunakan untuk membagi observasi pada "K" kelompok. Algoritma K-Means Clustering adalah sebagai berikut:

1. Peneliti menentukan jumlah klaster (K).

2. Pilih secara acak observasi dalam data untuk menentukan titik pusat (centroid) awal.

3. Menetapkan setiap observasi ke centroid terdekatnya berdasarkan jarak Euclidean antara observasi dengan centroid.

4. Untuk setiap klaster $\mathrm{K}$, perbarui centroid klaster dengan menghitung rata-rata baru dari semua titik data di dalam klaster.

5. Secara iteratif, minimalkan total withing sum of square menggunakan persamaan sebagai berikut:

$$
\text { tot. withiness }=\sum_{k=1}^{k} \sum_{x_{i} \in C_{k}}\left(x_{i}-\mu_{k}\right)^{2}
$$

dimana:

$x_{i}=$ titik data yang tergabung dalam klaster $C_{k}$

$\mu_{k}=$ nilai rata-rata dari titik data yang tergabung dalam klaster $C_{k}$

Ulangi langkah 3 dan 4 sampai proses pengelompokan data sudah tidak berubah atau iterasi maksimum sudah tercapai. Secara default, R software menggunakan 10 kali iterasi.

\section{Tahapan Analisis}

Variabel yang digunakan dalam penelitian ini adalah pertumbuhan ekonomi triwulan II-2020 yang bersumber dari Berita Resmi Statistik yang dirilis oleh BPS Provinsi seluruh Indonesia, Indeks Kerentanan Covid-19 yang bersumber dari Katadata, dan sektor basis lapangan usaha provinsi di Indonesia yang bersumber dari Publikasi PDRB Provinsi Menurut Lapangan Usaha Tahun 20152018. Observasi pada penelitian ini adalah 34 provinsi di Indonesia. Tahapan analisis pada penelitian ini adalah sebagai berikut :

1. Menghitung rata-rata nilai Location Quotient untuk mengetahui sektor basis pada masingmasing provinsi di Indonesia menggunakan data PDRB Provinsi Menurut Lapangan Usaha Tahun 2015-2018.

2. Melakukan analisis klaster menggunakan metode $K$-Means Clustering untuk mengetahui karakteristik pertumbuhan ekonomi dan sektor basis di masing-masing provinsi.

3. Interpretasi hasil dan pembahasan.

\section{HASIL DAN PEMBAHASAN}

\section{Karakteristik Sektor Basis Provinsi di Indonesia}

Berdasarkan perhitungan Location Quotient, hampir seluruh provinsi di Indonesia memiliki sektor basis pertanian sebagaimana dijelaskan oleh Gambar 1. Provinsi yang tidak memiliki sektor basis pertanian adalah DKI Jakarta, Jawa Barat, Banten, DI Yogyakarta, Jawa Timur, Kalimantan Timur, serta Papua dan Papua Barat. Dengan masih tumbuhnya sektor pertanian pada triwulan II2020, Indonesia seharusnya lebih tahan resesi daripada negara lain karena mempunyai modal lahan yang subur untuk pertanian. 


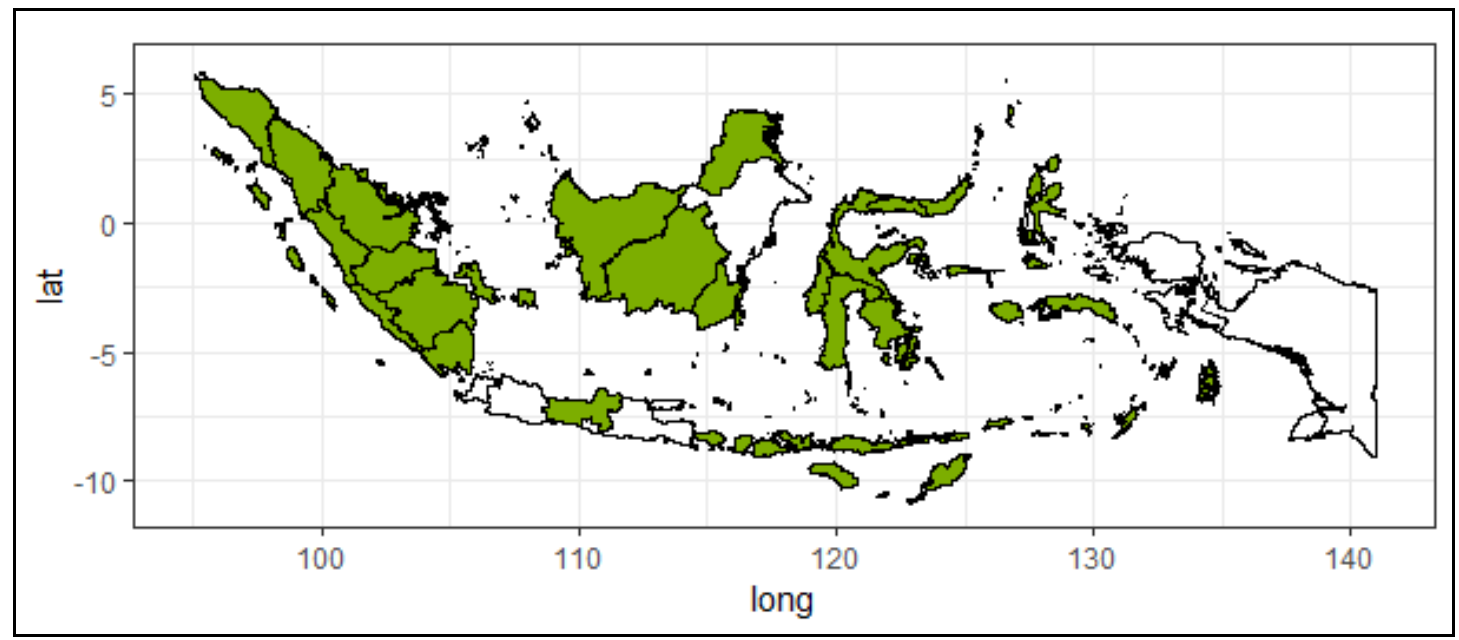

Gambar 1. Sektor Basis Pertanian di Indonesia

Kemudian Gambar 2 menjelaskan sebaran sektor basis industri di Indonesia. Terlihat bahwa sektor industri pengolahan terkonsentrasi di Pulau Jawa. Provinsi yang memiliki sektor basis industri pengolahan adalah Banten, Jawa Barat, Jawa Tengah, Jawa Timur, Sumatera Utara, Bangka Belitung, dan Papua Barat. Industri pengolahan memang menyumbang share yang besar terhadap PDB nasional. Pada triwulan II-2020, industri pengolahan terkontraksi 6,19 persen (BPS, 2020). Kontraksi industri pengolahan turut menyumbang 1,28 persen kontraksi PDB Nasional. Kontraksi sektor industri pengolahan juga disebabkan oleh Covid-19 yang menyebar di lingkungan pabrik. Sebagaimana dikutip dari CNN Indonesia (2020), Epidemiolog Universitas Griffith Australia menyebutkan bahwa klaster industri terjadi di Indonesia karena strategi pengendalian penularan Covid-19 di Indonesia yang belum memadai dari sisi testing dan pelacakan. Hal ini membuat masih banyaknya orang-orang terjangkit Covid-19 bisa berkeliaran di klaster pabrik dan perkantoran.

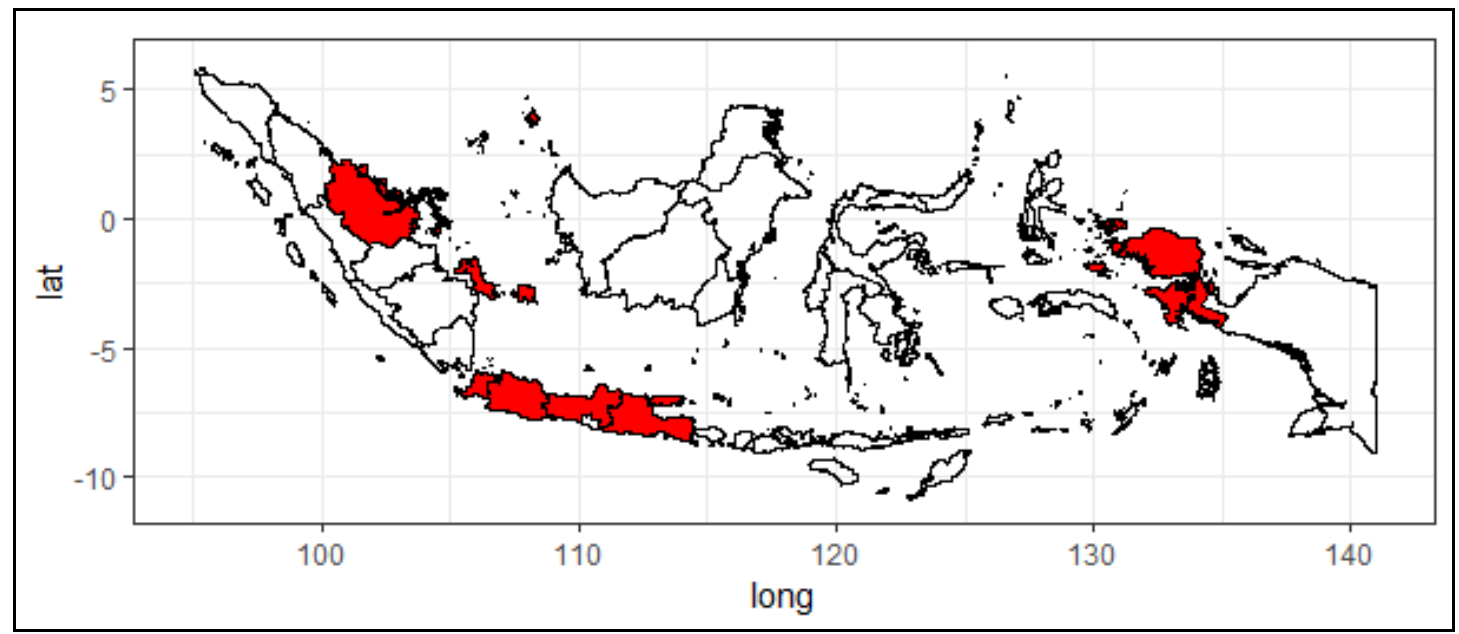

Gambar 2. Sektor Basis Industri Pengolahan di Indonesia

\section{Karakteristik Pertumbuhan Ekonomi di Masa Pandemi Covid-19}

Berdasarkan hasil perhitungan K-Means Clustering, terbentuk lima buah klaster seperti pada Tabel 1 dan Gambar 3. Setiap provinsi masuk ke dalam klaster yang memiliki kesamaan karakteristik dengan provinsi lainnya. Secara umum, provinsi yang tergabung dalam klaster 2 adalah provinsi yang mengalami kontraksi terdalam di Indonesia. Sementara provinsi yang tergabung dalam klaster 3 dan 4 adalah provinsi yang tidak terkontraksi terlalu dalam.

Provinsi DKI Jakarta, Banten, dan Jawa Barat, yang menyumbang 35,03 persen PDB nasional pada tahun 2019, adalah provinsi dengan kontraksi terparah pada triwulan II-2020. Dilihat dari sektor basisnya ketiga provinsi tersebut berbasis industri pengolahan dan perdagangan besar dan eceran. Ditambah lagi, indeks kerentanan Covid-19 di ketiga provinsi tersebut tergolong tinggi karena merupakan episentrum Covid-19 di Indonesia. 
Kemudian, provinsi yang tergabung dalam klaster 1 adalah provinsi yang bersektor basis campuran antara pertanian, industri pengolahan, dan perdagangan. Provinsi dalam klaster 2 tidak terkontraksi terlalu dalam karena terdapat sektor pertanian yang menahannya. Masa panen raya tanaman pangan pada triwulan II turut menahan laju kontraksi ekonomi di 12 provinsi tersebut. Selain itu, provinsi klaster 2 turut menyumbang 44,43 persen PDB Nasional. Dengan demikian, provinsi yang ada di klaster 2 dapat dijadikan harapan untuk memicu kembali perekonomian nasional dari sektor pertanian yang tidak turut terinfeksi Covid-19.

Lalu, provinsi yang tergabung dalam klaster 3 dan 4 relatif memiliki laju kontraksi yang minimal. Hal ini karena tingkat penularan Covid-19 di provinsi yang berada dalam klaster 3 dan 4 tidak terlalu masif dan perekonomiannya berbasis pertanian. Ditambah lagi, 19,36 persen PDB Indonesia disumbang oleh gabungan provinsi yang berada dalam klaster 3 dan 4.

Hal yang berbeda ditunjukkan oleh klaster 5 yang hanya beranggotakan Provinsi Papua. Papua berhasil tumbuh 4,52 persen karena terjadi peningkatan kinerja sektor pertambangan dan penggalian akibat naiknya produksi emas dan tembaga PT. Freeport selama periode triwulan II2020 (BPS Papua, 2020).

Dari hasil clustering, dapat diketahui bahwa provinsi yang berbasis sektor primer relatif tidak terkontraksi terlalu dalam di triwulan II-2020. Sementara provinsi yang berbasis sektor industri pengolahan dan perdagangan mengalami kontraksi yang sangat dalam akibat intensitas penularan Covid-19 di pabrik maupun di perkantoran. Selain itu, menurunnya konsumsi rumah tangga akibat PSBB juga turut andil dalam menurunkan performa ekonomi Indonesia.

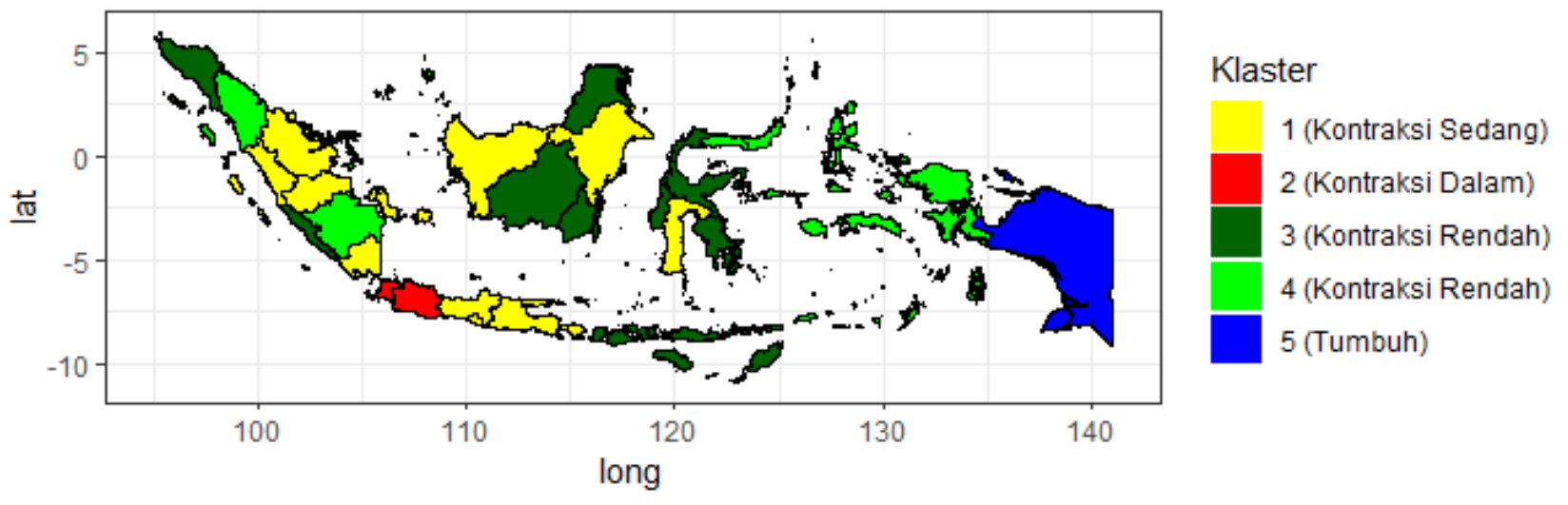

Gambar 3. Karakteristik Klaster Hasil K-Means Clustering

Tabel 1. Karakterstik Klaster Hasil K-Means Clustering

\begin{tabular}{|c|c|c|c|c|c|c|c|c|}
\hline \multirow[b]{2}{*}{ Klaster } & \multirow[b]{2}{*}{ Provinsi } & \multirow{2}{*}{$\begin{array}{c}\text { Rata-rata } \\
\text { Pertumbuhan } \\
\text { Ekonomi } \\
\text { Triwulan II } \\
2020(\%) \\
\end{array}$} & \multirow{2}{*}{$\begin{array}{c}\text { Kontribusi } \\
\text { Terhadap } \\
\text { PDB } \\
\text { Tahun } \\
2019 \\
\end{array}$} & \multirow[b]{2}{*}{$\begin{array}{l}\text { Rata-Rata } \\
\text { Indeks } \\
\text { Kerentanan } \\
\text { Covid }\end{array}$} & \multicolumn{4}{|c|}{ Jumlah Sektor Basis (Provinsi) } \\
\hline & & & & & Pertanian & Pertambangan & $\begin{array}{c}\text { Industri } \\
\text { Pengolahan }\end{array}$ & $\begin{array}{c}\text { Perdagangan } \\
\text { Besar dan } \\
\text { Eceran }\end{array}$ \\
\hline 1 & $\begin{array}{c}\text { Bangka Belitung, } \\
\text { Bali, Jambi, Jateng, } \\
\text { Jatim, Jogja, Kalbar, } \\
\text { Kaltim, Lampung, } \\
\text { Riau, Sulsel, Sumbar }\end{array}$ & $-4,74$ & 44,43 & 27,18 & 9 & 4 & 4 & 6 \\
\hline 2 & $\begin{array}{l}\text { Banten, Jabar, } \\
\text { Jakarta }\end{array}$ & $-7,20$ & 35,03 & 45,39 & 0 & 0 & 2 & 3 \\
\hline 3 & $\begin{array}{c}\text { Aceh, Bengkulu, } \\
\text { Kalsel, Kaltara, } \\
\text { Kalteng, NTB, NTT, } \\
\text { Sulbar, Sulteng, } \\
\text { Sultra }\end{array}$ & $-1,89$ & 7,74 & 22,19 & 10 & 6 & 0 & 2 \\
\hline 4 & $\begin{array}{l}\text { Gorontalo, Kepri, } \\
\text { Maluku, Maluku } \\
\text { Utara, Papua Barat, } \\
\text { Sulut, Sumsel, } \\
\text { Sumut. }\end{array}$ & $-1,89$ & 11,62 & 30,86 & 6 & 4 & 2 & 3 \\
\hline 5 & Papua & 4,52 & 1,18 & 21,45 & 0 & 1 & 0 & 0 \\
\hline
\end{tabular}




\section{Hubungan Pertumbuhan Ekonomi dengan Indeks Kerentanan Covid-19 Provinsi}

Selain diakibatkan oleh konsentrasi sektor basis, pertumbuhan ekonomi di masing-masing provinsi juga ada hubungannya dengan indeks kerentanan Covid-19. Seperti pada Gambar 3, provinsi yang berada di Pulau Jawa memiliki indeks kerentanan Covid-19 yang tinggi dan pertumbuhan ekonomi yang minus cukup dalam. Hal ini disebabkan karena Pulau Jawa yang merupakan pulau terpadat di Indonesia dengan mobilitas penduduk yang tinggi serta rapuhnya sistem layanan kesehatan membuat Pulau Jawa sangat rentan bahkan menjadi episentrum Covid19 di Indonesia. Kondisi kesehatan dan perekonomian ini bisa bertambah buruk apalagi DKI Jakarta, sebagai provinsi yang "paling siap" menghadapi Covid-19, memprediksi bahwa rumah sakit dan ruang ICU akan penuh pada 17 September 2020 sehingga harus menarik "rem darurat". Memburuknya kondisi di DKI Jakarta harus diwaspadai oleh daerah lain berhubung fasilitas kesehatan dan SDM yang dimiliki daerah lain tidak "sesiap" Jakarta sebagai ibukota negara.

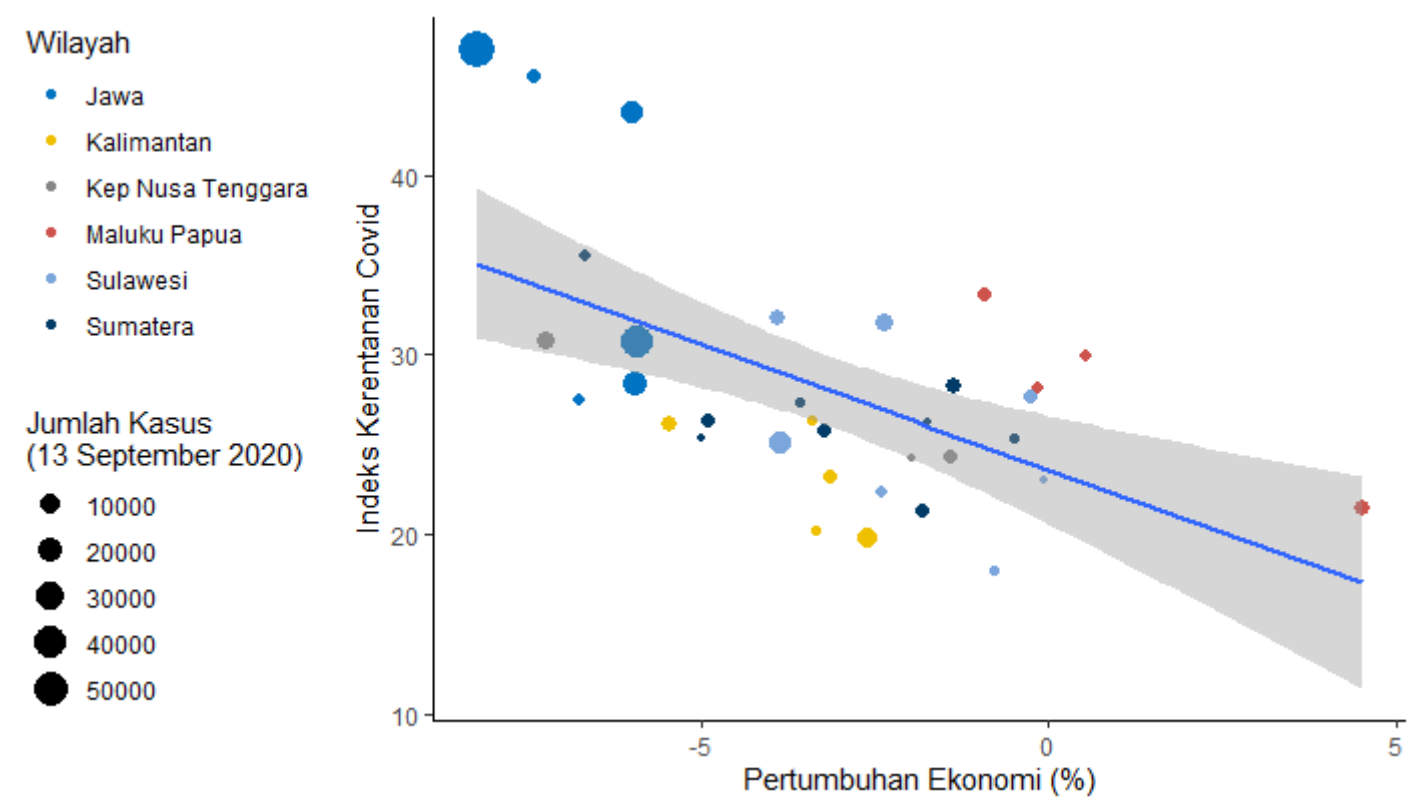

Sumber : BPS, Katadata, dan Satgas Covid-19 (diolah)

Gambar 3. Hubungan Pertumbuhan Ekonomi dan Indeks Kerentanan Covid-19

\section{KESIMPULAN}

Berdasarkan ulasan di atas dapat disimpulkan bahwa provinsi yang tidak terkontraksi di masa pandemi Covid-19 adalah yang memiliki sektor basis pertanian. Sebaliknya, provinsi yang berbasis industri pengolahan dan perdagangan terkontraksi cukup dalam. Hal ini disebabkan karena terjadinya penularan Covid-19 di pabrik-pabrik maupun perkantoran sehingga sebagian proses produksi terhenti. Dengan demikian, pemerintah hendaknya "memulihkan" ekonomi yang dimulai dari sektor pertanian. Selain itu, kontraksi pertumbuhan ekonomi juga berhubungan dengan kerentanan Covid-19 di masing-masing provinsi. Mulai rapuhnya sistem kesehatan di DKI Jakarta harus menjadi refleksi provinsi-provinsi lain di Indonesia dalam mengatasi pandemi dan memulihkan perekonomian.

\section{DAFTAR PUSTAKA}

Bendavid, A.-L. (1991). Regional and Local economic analysis for practitioners 4th Ed. New York: Praeger.

BPS. (2020). Berita Resmi Statistik : Pertumbuhan Ekonomi Indonesia Triwulan II-2020. Jakarta: Badan Pusat Statistik. Diambil kembali dari 
https://www.bps.go.id/pressrelease/2020/08/05/1737/-ekonomi-indonesia-triwulan-ii-2020turun-5-32-persen.html

BPS Papua. (2020). Pertumbuhan Ekonomi Papua Triwulan II 2020. Diambil kembali dari Badan Pusat Statistik Provinsi Papua:

https://papua.bps.go.id/pressrelease/2020/08/05/486/pertumbuhan-ekonomi-papuatriwulan-ii-2020.html

CNN Indonesia. (2020). Epidemiolog Respons Klaster Industri Penularan Corona. Diambil kembali dari cnnindonesia.com: https://www.cnnindonesia.com/teknologi/20200904194556-199542993/epidemiolog-respons-klaster-industri-penularan-corona

Katadata. (2020). 2.880 Kasus Baru Corona RI, 66 Persen Disumbang Pulau Jawa. Diambil kembali dari Katadata.co.id: https://katadata.co.id/ameidyonasution/berita/5f5609acf1b75/2880kasus-baru-corona-ri-66-persen-disumbang-pulau-jawa

Katadata. (2020). Kesiapan Daerah Hadapi Pandemi Covid-19 : Indeks Kerentanan Provinsi / Katadata Webinar. Diambil kembali dari Youtube:

https://www.youtube.com/watch?time_continue=587\&v=TgynhPFBr2Q\&feature=emb_logo

Olivia, S., Gibson, J., \& Nasrudin, R. (2020). Indonesia in the Time of Covid-19. Bulletin of Indonesian Economic Studies, 56(2), 143-174. doi:10.1080/00074918.2020.1798581

Satgas Covid-19. (2020, September 14). Data Covid-19. Diambil kembali dari Satuan Tugas Penanganan Covid-19: https://covid19.go.id/peta-sebaran

Tempo. (2020). 59 Negara Larang Kunjungan WNI, Ini Respons INACA dan Bos Garuda Indonesia . Diambil kembali dari Tempo.co: https://bisnis.tempo.co/read/1384273/59-negara-larangkunjungan-wni-ini-respons-inaca-dan-bos-garuda-indonesia/full\&view=ok

Tirto. (2020). Anies Dikepung Protes Menteri Jokowi sebab PSBB Picu Ekonomi Anjlok. Diambil kembali dari Tirto.id: https://tirto.id/anies-dikepung-protes-menteri-jokowi-sebab-psbbpicu-ekonomi-anjlok-f386

Todaro, M. P., \& Smith, S. C. (2011). Economic Development (11th ed.). Harlow: Pearson Education Limited.

University of Cincinnati. (2018). K-means Cluster Analysis. Diambil kembali dari UC Business Analytics R Programming Guide: https://uc-r.github.io/kmeans_clustering

Wibisono, Y. (2003). Determinan pertumbuhan regional: studi empiris antar provinsi di Indonesia. Jurnal Ekonomi dan Pembangunan.

Wisana, I. D. (2001). Kesehatan Sebagai Suatu Investasi. Jurnal Ekonomi dan Pembangunan Indonesia, 1(1), 42-51. doi:https://doi.org/10.21002/jepi.v1i2.613 


\section{LAMPIRAN}

Hasil K-Means Clustering

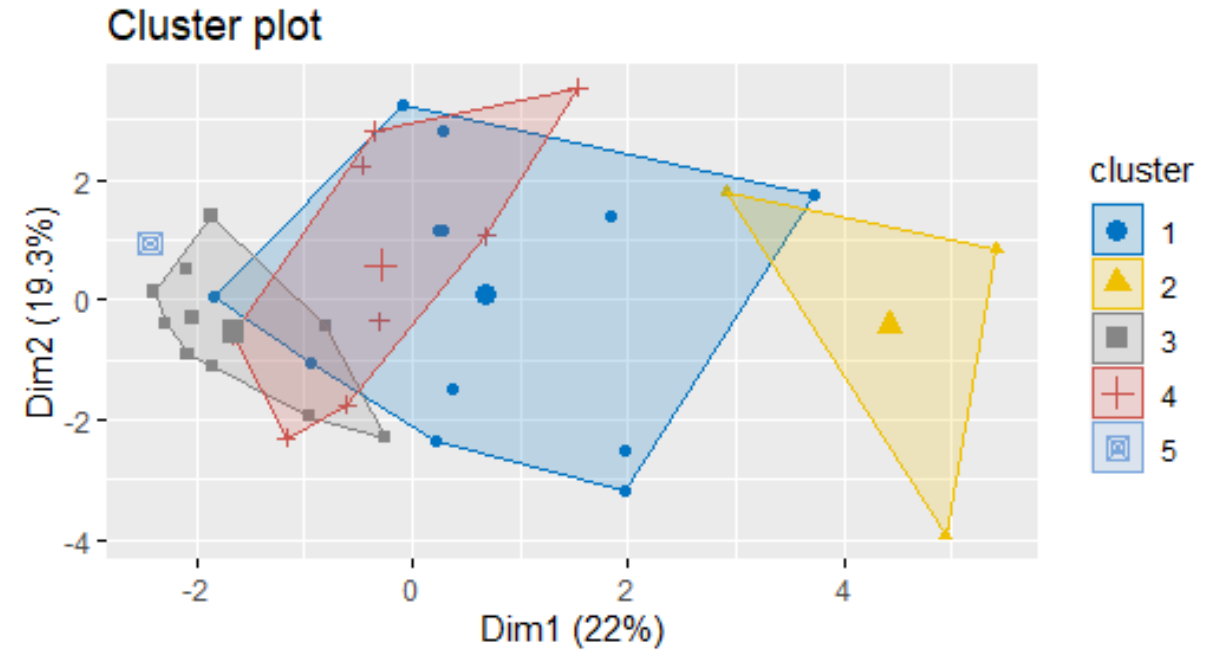

